\title{
Molecular Epidemiology of Methicillin-resistant Staphylococcus aureus in Children: Comparison between Cystic Fibrosis and Non-cystic Fibrosis Isolates
}

\begin{abstract}
Sir,
We have previously reported, elsewhere and separately, the molecular and phenotypical characteristics of methicillinresistant Staphylococcus aureus (MRSA) isolates from cystic fibrosis patients and from non-cystic fibrosis patients. ${ }^{[1,2]}$ We aimed to perform a molecular comparison between the isolates from the two groups, using pulsed field gel electrophoresis (PFGE).

Thirty seven MRSA isolates were included, nine from cystic fibrosis patients (respiratory secretion), and 30 from non-cystic fibrosis, hospitalized patients (from
\end{abstract}


various anatomical sites). One patient with cystic fibrosis and three patients without cystic fibrosis had two isolates included each. Of the 39 isolates, one carried SCCmec type I, three SCCmec type II, 19 SCCmec type III, and 16 SCCmec type IV. DNA restriction patterns after digestion were analysed by PFGE, which was performed as described previously. ${ }^{[3]}$ Results were compared using the GelComparII software (Applied Maths, Kortrijk, Belgium), based on published criteria. ${ }^{[4]}$

Cystic fibrosis isolates were similar to non-cystic fibrosis isolates. We observed clustering within SCCmec types (notably types III and IV, that were more numerous), but not within groups of isolates (cystic fibrosis versus non-cystic fibrosis). Most type III isolates had patterns typical of the Brazilian clone, whereas the majority of type IV isolates were at least similar to the SCCmec IV pediatric clone. These findings suggest that the local of acquisition of MRSA isolates could be the same (probably the hospital) for most of the cystic fibrosis and noncystic fibrosis patients. Prospective studies with a higher number of isolates are necessary to clarify the details of the epidemiological relationship between MRSA isolates in these patients.

\section{Marcelo Jenne Mimica, ${ }^{1,2}$, Eitan Naaman Berezin ${ }^{1}$, Neiva Damaceno', Rozane Bigelli Carvalho ${ }^{2}$}

Departments of ${ }^{1}$ Pediatrics and ${ }^{2}$ Pathology, Santa Casa School of Medicine, Rua Cesário Mota Jr., 61, São Paulo, Brazil

Address for correspondence: Dr. Marcelo Mimica, E-mail:mjmimica@hotmail.com

\section{REFERENCES}

1. Mimica MJ, Berezin EN, Carvalho RB. Healthcare associated PVL-negative methicillin-resistant Staphylococcus aureus with SCCmec type IV. Pediatr Infect Dis J 2009;28:934.

2. Mimica MJ, Berezin EN, Damaceno N, Carvalho RB. SCCmec Type IV, PVL-Negative, Methicillin-Resistant Staphylococcus aureus in Cystic Fibrosis Patients from Brazil. Curr Microbiol 2011;62:388-90.

3. Hultén KG, Kaplan SL, Gonzalez BE, Hammerman WA, Lamberth LB, Versalovic J, et al. Three-yearsurveillance of community onset health careassociated Staphylococcus aureus infections in children. Pediatr Infect Dis J 2006;25:349-53.

4. Tenover FC, Arbeit RD, Goering RV, Mickelsen PA, Murray BE, Persing $\mathrm{DH}$, et al. Interpreting chromosomal DNA restriction patterns produced by pulsed-fieldgel electrophoresis: criteria for bacterial strain typing. J Clin Microbiol 1995;33:2233-9.

\begin{tabular}{|l|l|}
\hline \multicolumn{2}{|c|}{ Access this article online } \\
\hline Quick Response Code: & Website: \\
\hline & www.jlponline.org \\
\hline & \\
\hline
\end{tabular}

